Speciucens reqistered

\title{
Mydragrapstic Sheet,
}

\section{Sea Bottom Specimens.}

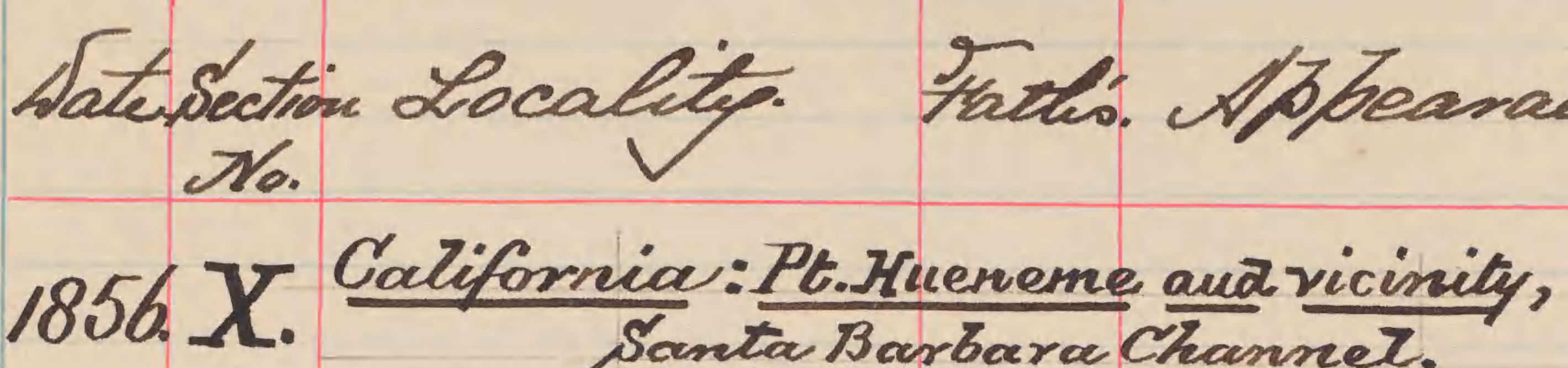

$$
\begin{aligned}
& \text { Angle No.r, } 6 \text { day } \\
& \text { " } 3 \% \text {." } \\
& \text { " "4 } 4 \pi_{2, " .} \\
& \text { " } 50, \text {. } \\
& \text { - } 384, C \\
& \text { " " } 9, \text {, . } \\
& \text { ". 16, . . } \\
& \text { - "2r, 。 } \\
& \text { ". } 2602 \% \\
& \text { " "2यp28," } \\
& \text { " } 28, " \\
& \text { " "35," } \\
& \text { " } 38, " . \\
& \text { " "44,". } \\
& \text { ielegith". }
\end{aligned}
$$

$2 x$

*aro.

1\%.
Boxefroent Tha. Na. 